\title{
PENGARUH EKSTRAK DAUN PEPAYA TERHADAP PENYAKIT ANTRAKNOSA PADA BUAH PEPAYA
}

\section{THE EFFECT OF PEPAYA LEAVES EXTRACT ON ANTHRACNOSE DISEASE IN PEPAYA FRUIT}

\author{
Muhammad Asep Awaludin*, Efri, Sudiono \\ Jurusan Agroteknologi Fakultas Pertanian Universitas Lampung \\ Jalan Prof. Dr. soemantri Brojonegoro No.1 Bandar Lampung 35145 \\ *Email:muhammadasep14@gmail.com
}

\begin{abstract}
Papaya is a plant that can be used as a botanical fungicide. This research aims to determine the effect of papaya leaves extract on growth Colletotrichum gloeosporioides in-vitro and the intensity of anthracnose disease in papaya fruit in-vivo. The research was arranged in a completely randomized design consisting of seven treatments and four replications. The data obtained were analyzed by variance, then the middle values were compared and tested with the smallest significant difference test at the 5\% level and the polynomial test at the 5\% level. The results showed a significant effect of papaya leaves extract and synthetic fungicide in inhibiting the growth of C. gloeosporioides colonies, the occurrence of disease, and the rate of development of anthracnose disease in papaya fruit. Papaya leaves extract shows a linear pattern of polynomial test results on the diameter of $C$. gloeosporioides colony and the rate of disease development. Papaya leaves extract inhibits the growth of C. gloeosporioides fungal colonies at 2 to 7 hsi, occurrence of disease at 5 and $6 \mathrm{hsa}$, as well as the development rate of anthracnose disease in papaya fruit. However, papaya leaves extract does not inhibit spore density, germination spore, and severity of the disease.
\end{abstract}

Keywords: Colletotrichum gloeosporioides, vegetable fungicide, rate of development, severity, occurrence.

\begin{abstract}
ABSTRAK
Pepaya merupakan tanaman yang dapat dimanfaatkan sebagai fungisida nabati. Penelitian ini bertujuan untuk mengetahui pengaruh ekstrak daun pepaya terhadap pertumbuhan Colletotrichum gloeosporioides secara invitro dan intensitas penyakit antraknosa pada buah pepaya secara in-vivo. Penelitian disusun dalam rancangan acak lengkap yang terdiri atas tujuh perlakuan dan empat ulangan. Data yang diperoleh dianalisis dengan sidik ragam selanjutnya nilai tengah dibandingkan dan diuji dengan uji beda nyata terkecil pada taraf $5 \%$ dan uji polinomial pada taraf $5 \%$. Hasil penelitian menunjukkan pengaruh yang nyata dari ekstrak daun pepaya dan fungisida sintetik dalam menghambat pertumbuhan koloni $C$. gloeosporioides, keterjadian penyakit, dan laju perkembangan penyakit antraknosa pada buah pepaya. Ekstrak daun pepaya menunjukan pola yang linier dari hasil uji polinomial terhadap diameter koloni C. gloeosporioides dan laju perkembangan penyakit. Ekstrak daun pepaya menghambat pertumbuhan koloni jamur $C$. gloeosporioides pada 2 sampai 7 hsi (hari setelah inokulasi),
\end{abstract}


keterjadian penyakit pada 5 dan 6 hsa (hari setelah aplikasi), maupun laju perkembangan penyakit antraknosa pada buah pepaya. Tetapi ekstrak daun pepaya tidak menghambat kerapatan spora, perkecambahan spora, dan keparahan penyakit.

Kata kunci: Colletotrichum gloeosporioides, fungisida naabati, laju perkembangan, keparahan, keterjadian.

\section{PENDAHULUAN}

Pepaya (Carica papaya L.) merupakan tanaman yang umum terdapat di Indonesia. Pepaya memilikibuah yangkaya akan gizi. Buah ini mengadung enzim-enzim, vitamin A, B, C dan E, serta mineral (Kharisma, 2017). Permintaan buah pepaya untuk kebutuhan lokal maupun ekspor dari tahun ke tahun semakin meningkat, akan tetapi kenyataanya produksi buah pepaya di Indonesia menurun. Produksi pepaya pada tahun 2016 sebesar 904.284 ton (BPS, 2016), sedangkan pada tahun 2017 menurun menjadi sebesar 875.112 ton (BPS, 2017). Penurunan produksi tersebut disebabkan oleh kerusakan buah dari penanganan pascapanen yang salah atau karena serangan organisme pengganggu tanaman seperti jamur patogen.

Salah satu jamur patogen pada tanaman papaya adalah Colletotrichum gloeosporioides yang menyebabkan penyakit antraknosa pada buah pepaya. Jamur patogen tersebut menyebabkan timbulnya bercak-bercak coklat kemerahan, kebasah-basahan, kecil, dan bulat pada buah yang menjelang matang. Pada waktu buah matang bercak tersebut membesar dengan cepat, membentuk bercak bulat, cokelat kemerahan, yang agak mengendap. Selanjutnya jamur patogen ini akan terus berkembang dan membusukan bagian dalam buah sehingga jaringan buah membusuk, menjadi lunak, dan berwarna agak gelap(Semangun, 2007).

Pada umumnya petani mengendalikan penyakit antraknosa menggunakan fungisida sintetik. Penggunaan fungisida secara terus-menerus menyebabkan peningkatan biaya produksi, resiko kesehatan petani, serta merusak lingkungan. Efek buruk yang ditimbulkan oleh fungisida sintetik tersebut membuat perlu adanya alternatif yang lebih aman untuk kesehatan dan ramah lingkungan. Penggunaan fungisida nabati dari ekstrak tumbuh-tumbuhan merupakan salah satu alternatif untuk mengatasi penyakit antraknosa yang lebih aman dan ramah lingkungan (Septiana dkk., 2013).

Salah satu tanaman yang berpotensi sebagai fungisida nabati ialah pepaya. Daun pepaya merupakan bagian tanaman pepaya yang dimanfaatkan menjadi fungisida nabati. Daun pepaya muda banyak mengandung zat aktif enzim papain dan alkaloid yang bersifat bakterisida dan fungisida (Ariani, 2006). Oleh sebab itu, ekstrak daun pepaya dapat digunakan sebagai fungisida nabati sebagai pengganti fungisida sintetik. Penelitian ini bertujuan untuk mengetahui pengaruh ekstrak daun pepaya terhadap pertumbuhan C. gloeosporioides secara in-vitro dan intensitas penyakit antraknosa pada buah pepaya (Carica papaya L.) secara in-vivo. 


\section{BAHAN DAN METODE}

Penelitian dilakukan di Laboratorium Penyakit Tumbuhan serta Laboratorium Bioteknologi, Fakultas Pertanian, Universitas Lampung dan dilaksanakan pada bulan Februari 2019 sampai dengan Mei 2019. Penelitian disusun dalam rancangan acak lengkap (RAL) yang terdiri atas tujuh perlakuan dan empat ulangan, yaitu kontrol dengan Antracol 70 WP yang berbahan aktif propinep 70\% sebagai fungisida sintetik (P1), kontrol tanpa fungisida (P2), ekstrak daun pepaya konsentrasi 10\% (P3), ekstrak daun pepaya konsentrasi 20\% (P4), ekstrak daun pepaya konsentrasi 30\% (P5), ekstrak daun pepaya konsentrasi 40\% (P6), dan ekstrak daun pepaya konsentrasi 50\%(P7). Setiap perlakuan dilakukan secara duplo (2 set). Penelitian dilakukan dengan dua tahap, yaitu uji ekstrak daun pepaya terhadap penghambatan pertumbuhan jamur $C$. gloeosporioides secara in-vitro dan uji ekstrak daun pepaya terhadap intensitas penyakit antraknosa pada buah pepaya secara in-vivo.

Data yang diperoleh dianalisis dengan sidik ragam selanjutnya nilai tengah dibandingkan dan diuji

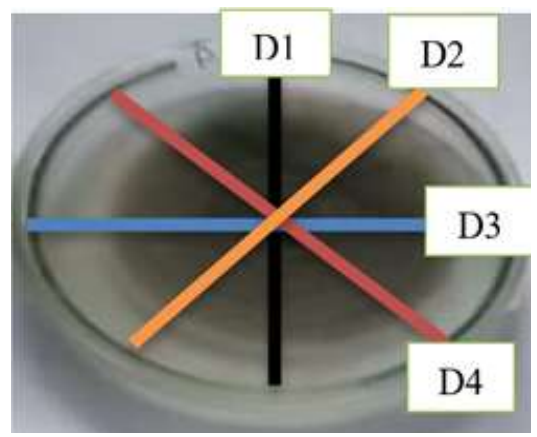

Gambar 1. Ilustrasi pengukuran diameter koloni C. gloeosporioides dari empat arah yang berbeda (D1, D2, D3, D4). dengan uji beda nyata terkecil (BNT) pada taraf 5\% dan uji polinomial pada taraf 5\%. Parameter pengamatan secara in-vitro yaitu diameter koloni C. gloeosporioides, kerapatan spora C. gloeosporioides, dan perkecambahan spora C. gloeosporioides.

Perhitungan diameter koloni dilakukan dengan rumus sebagai berikut :

$$
\mathrm{D}=\frac{\mathrm{D} 1+\mathrm{D} 2+\mathrm{D} 3+\mathrm{D} 4}{4}
$$

Keterangan: $\mathrm{D}=$ Diameter koloni $C$. gloeosporioides (cm); D1, D2, D3, D4 = Panjang koloni $C$. gloeosporioides $(\mathrm{cm})$ hasil pengukuran dari empat arah yang berbeda.

Kerapatan spora C. gloeosporioides dapat dihitung dengan menggunakan rumus sebagai berikut (Gabriel dan Riyanto, 1989):

$$
C=\frac{t}{n} \times 0,25 \times 10^{6}
$$

Keterangan :

C $=$ Kerapatan spora/ml suspensi

$$
\text { C. gloeosporioides }
$$

$\mathrm{t}=$ Jumlah total spora dalam kotak sampel yang diamati

$\mathrm{n} \quad=$ Jumlah kotak sampel (5 kotak sedang)

0,25 =Faktor koreksi penggunaan kotak sampel skala sedang pada haemacytometer.

Perkecambahan spora dapat dihitung dengan menggunakan rumus sebagai berikut:

$$
\text { Perkecambahan Spora }=\frac{\text { Jumlah spora berkecambah }}{\text { Jumlah pora tidak berkecambah }} \times 100 \%
$$


Sedangkan parameter pengamatan secara invivo yaitu keterjadian penyakit antraknosa pada buah pepaya, keparahan penyakit antraknosa pada buah pepaya, dan perkembangan penyakit antraknosa pada buah pepaya. tumbuh koloni C. gloeosporioides dan kerapatan spora C. gloeosporioides

Keterjadian penyakit dapat dihitung menggunakan rumus sebagai berikut (Ginting, 2013):

$$
\text { Keterjadian Penyakit }=\frac{\text { Jumlah titik yang menunjukan gejala }}{\text { Jumlah titik yang diamati (sampel) }} \times 100 \%
$$

Keparahan penyakit dapat dihitung dengan menggunakan rumus sebagai berikut (Ginting, 2013) :

$$
\text { Keparahan Penyakit }=\frac{\text { Luas permukaan buah pepaya bergejala }}{\text { Luas permukaan keseluruhan buah pepaya }} \times 100 \%
$$

Perkembangan penyakit dari waktu ke waktu dihitung dengan rumus AUDPC (Apriyadi dkk., 2013):

$$
\operatorname{AUDPC}=\sum_{i=1}^{n-i}\left(\left(Y_{i}+Y_{i+1}\right) / 2\right) \cdot\left(t_{i+1}-t\right)
$$

Keterangan :

$$
\begin{aligned}
& \text { AUDPC }=\text { Area Under the Disease Progress Curve } \\
& \begin{aligned}
\mathrm{Y} & =\text { Keparahan penyakit } \\
\mathrm{I} & =\text { Jumlah hari setelah aplikasi } \\
\mathrm{t} & =\text { Waktu pengamatan }
\end{aligned}
\end{aligned}
$$

\section{HASIL DAN PEMBAHASAN}

Pengaruh Ekstrak Daun Pepaya terhadap Pertumbuhan C.gloeosporioides.

Hasil analisis ragam pengaruh ekstrak daun pepaya dan fungisida sintetik terhadap pertumbuhan koloni C. gloeosporioides menunjukan adanya pengaruh yang nyata dalam menghambat pertumbuhan koloni tersebut (Tabel 1). Ekstrak daun pepaya dan fungisida sintetik berpengaruh nyata menghambat pertumbuhan koloni C. gloeosporioides mulai dari 2 sampai 7 hari setelah inokulasi (hsi). Sedangkan pada 8 sampai 10 hsi ekstrak daun pepaya sudah tidak berpengaruh nyata menghambat pertumbuhan koloni C. gloeosporioides.

Berdasarkan uji beda nyata terkecil (BNT) pengaruh perlakuan ekstrak daun pepaya konsentrasi $10 \%$ berbeda nyata dalam menghambat pertumbuhan koloni C. gloeosporioides dibandingkan dengan kontrol tanpa fungisida dari 2 sampai 4 hsi. Akan tetapi, pengaruh perlakuan ekstrak daun pepaya konsentrasi $20,30,40,50 \%$ berbeda nyata dalam menghambat pertumbuhan koloni C. gloeosporioides dibandingkan dengan kontrol tanpa fungisida dari 2 sampai 7 hsi. Selain itu, pengaruh fungisida sintetik berbahan aktif propineb $70 \%$, menunjukan perbedaan yang nyata dalam menghambat pertumbuhan koloni

C. gloeosporioides dibandingkan dengan kontrol tanpa fungisida dari 2 sampai 7 hsi. Berdasarkan hasil tersebut, kemampuan ekstrak daun pepaya $20,30,40$ dan $50 \%$ dalam menghambat pertumbuhan koloni C. gloeosporioides sama dengan kontrol fungisida sintetik berbahan aktif propineb $70 \%$.

Ekstrak daun pepaya dan fungisida sintetik memiliki daya hambat terhadap pertumbuhan koloni C. gloeosporioides dibandingkan dengan kontrol tanpa fungisida (Gambar 2). Ekstrak daun pepaya konsentrasi 50\%(P7) merupakan konsentrasi terbaik yang memiliki daya hambat paling kuat terhadap 
Tabel 1. Pengaruh perlakuan ekstrak daun pepaya dan fungisida sintetik terhadap pertumbuhan koloni C. gloeosporioides

\begin{tabular}{lccccccccc}
\hline \multirow{2}{*}{ Perlakuan } & \multicolumn{7}{c}{ Rata-rata diameter $(\mathrm{cm})$} \\
\cline { 2 - 10 } & 2 hsi & $3 \mathrm{hsi}$ & $4 \mathrm{hsi}$ & $5 \mathrm{hsi}$ & $6 \mathrm{hsi}$ & $7 \mathrm{hsi}$ & $8 \mathrm{hsi}$ & 9 hsi & $10 \mathrm{hsi}$ \\
\hline P1 & $0,500 \mathrm{a}$ & $0,738 \mathrm{a}$ & $1,200 \mathrm{a}$ & $1,819 \mathrm{a}$ & $2,394 \mathrm{a}$ & $3,094 \mathrm{a}$ & 3,731 & 4,238 & 4,600 \\
P2 & $1,038 \mathrm{~b}$ & $1,988 \mathrm{~b}$ & $3,138 \mathrm{~b}$ & $4,250 \mathrm{~b}$ & $5,369 \mathrm{c}$ & $6,656 \mathrm{c}$ & 7,794 & 8,531 & 8,900 \\
P3 & $0,638 \mathrm{a}$ & $1,225 \mathrm{a}$ & $2,063 \mathrm{a}$ & $3,100 \mathrm{ab}$ & $3,981 \mathrm{bc}$ & $5,094 \mathrm{bc}$ & 6,013 & 7,013 & 7,919 \\
P4 & $0,500 \mathrm{a}$ & $0,806 \mathrm{a}$ & $1,788 \mathrm{a}$ & $2,669 \mathrm{a}$ & $3,575 \mathrm{ab}$ & $4,663 \mathrm{ab}$ & 5,694 & 6,700 & 7,700 \\
P5 & $0,544 \mathrm{a}$ & $0,944 \mathrm{a}$ & $1,731 \mathrm{a}$ & $2,663 \mathrm{a}$ & $3,375 \mathrm{ab}$ & $4,319 \mathrm{ab}$ & 5,269 & 6,181 & 7,219 \\
P6 & $0,531 \mathrm{a}$ & $0,800 \mathrm{a}$ & $1,475 \mathrm{a}$ & $2,281 \mathrm{a}$ & $3,319 \mathrm{ab}$ & $4,431 \mathrm{ab}$ & 5,519 & 6,650 & 7,625 \\
P7 & $0,500 \mathrm{a}$ & $0,681 \mathrm{a}$ & $1,394 \mathrm{a}$ & $2,225 \mathrm{a}$ & $2,969 \mathrm{ab}$ & $3,888 \mathrm{ab}$ & 4,744 & 5,650 & 6,531 \\
\hline F hitung & 6,586 & 4,614 & 3,354 & 3,093 & 3,123 & 2,781 & 2,486 & 2,192 & 2,041 \\
\hline F tabel & 2,573 & 2,573 & 2,573 & 2,573 & 2,573 & 2,573 & 2,573 & 2,573 & 2,573 \\
\hline Kesimpulan & $*$ & $*$ & $*$ & $*$ & $*$ & $*$ & TN & TN & TN \\
\hline BNT 5\% & 0,225 & 0,630 & 1,034 & 1,320 & 1,557 & 1,953 & - & - & - \\
\hline
\end{tabular}

Keterangan : P1 = Fungisida sintetik, P2 = Kontrol tanpa fungisida, P3 = Ekstrak daun pepaya 10\%, P4 = Ekstrak daun pepaya $20 \%$, P5 = Ekstrak daun pepaya $30 \%$, P6 = Ekstrak daun pepaya 40\%, P7 = Ekstrak daun pepaya $50 \%$, $\mathrm{TN}=$ Tidak Nyata,$*=$ Nyata.

pertumbuhan koloni C. gloeosporioides dibandingkan dengan ekstrak daun pepaya konsentrasi lainnya.

Berdasarkan hasil uji polinomial konsentrasi ekstrak daun pepaya terhadap pertumbuhan koloni $C$. gloeosporioides menunjukan pola yang linier, yang disajikan dengan persamaan

$$
(\mathrm{Y}=-0,1857 \mathrm{x}+23,476) \text {. Hasil tersebut }
$$

menunjukan bahwa semakin tinggi konsentrasi ekstrak daun pepaya maka daya hambat terhadap pertumbuhan koloni C. gloeosporioides semakin kuat (Gambar 3).

Pengamatan pengaruh ekstrak daun pepaya dan fungisida sintetik terhadap kerapatan spora disajikan pada Tabel 2, dan perkecambahan spora setelah 14 jam disajikan pada Tabel 3. Hasil analisis ragam pengaruh ekstrak daun pepaya dan fungisida sintetik terhadap kerapatan dan perkecambahan spora menunjukan tidak adanya pengaruh yang nyata dalam menghambat kerapatan dan perkecambahan spora. Berdasarkan hasil tersebut ekstrak daun pepaya dan fungisida sintetik berbahan aktif propineb $70 \%$ tidak mampu menghambat kerapatan dan perkecambahan spora C. gloeosporioides.

Hasil pengujian secara in-vitro menunjukkan bahwa ekstrak daun pepaya menghambat pertumbuhan koloni $C$. gloeosporioides dari 2 sampai 7 hsi. Hal tersebut diduga karena adanya kandungan senyawa aktif pada daun pepaya muda seperti papain dan alkaloid. Papain merupakan enzim protase yang dapat mengurai protein(Yulianty dkk., 2018). Protein yang terurai menyebabkan denaturasi protein sehingga protein jamur menjadi rusak dan pertumbuhannya terganggu. Alkaloid merupakan senyawa yang bersifat 


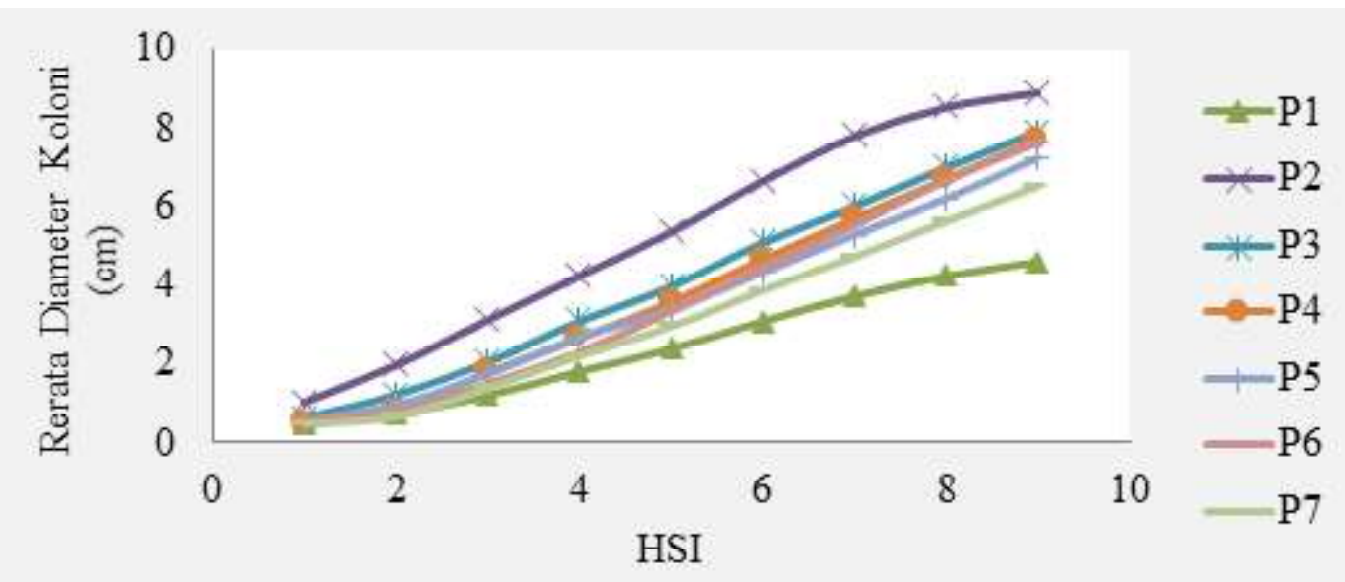

Gambar 2. Grafik pengaruh perlakuan ekstrak daun pepaya dan fungisida sintetik terhadap pertumbuhan koloni $C$. gloeosporioides pada 2 sampai 10 hsi.

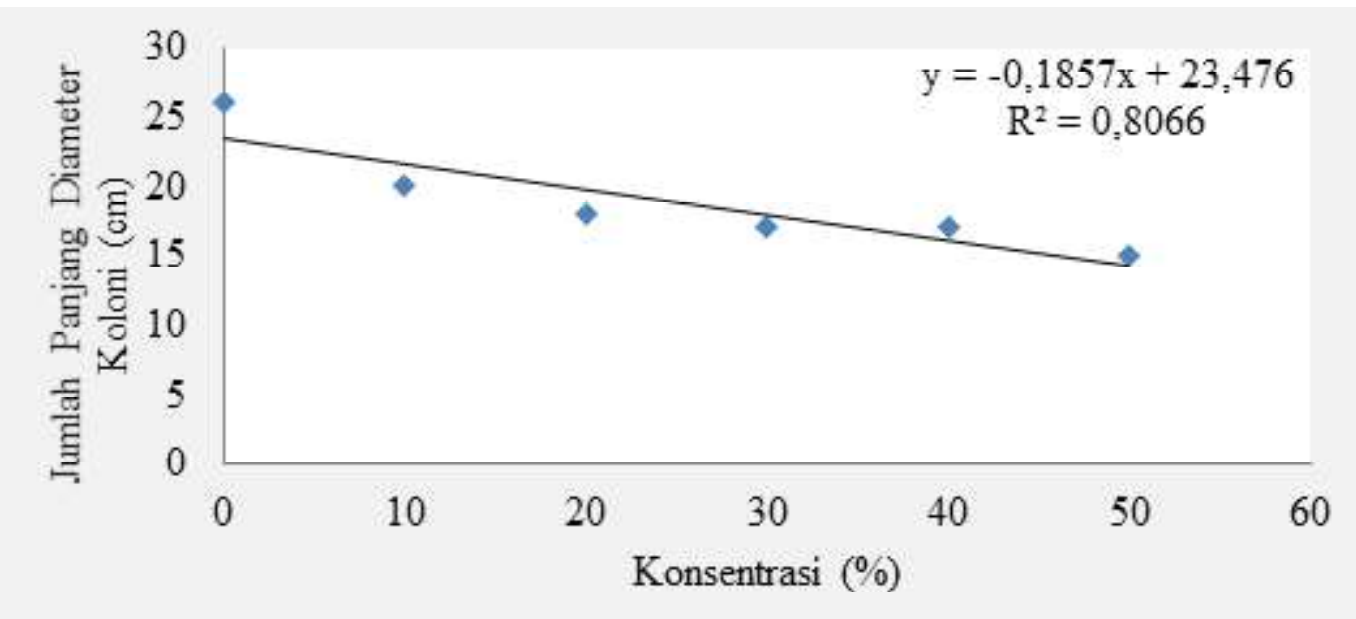

Gambar 3. Grafik pertumbuhan koloni C. gloeosporioides dari beberapa konsentrasi ekstrak daun pepaya pada 7 hari setelah inokulasi.

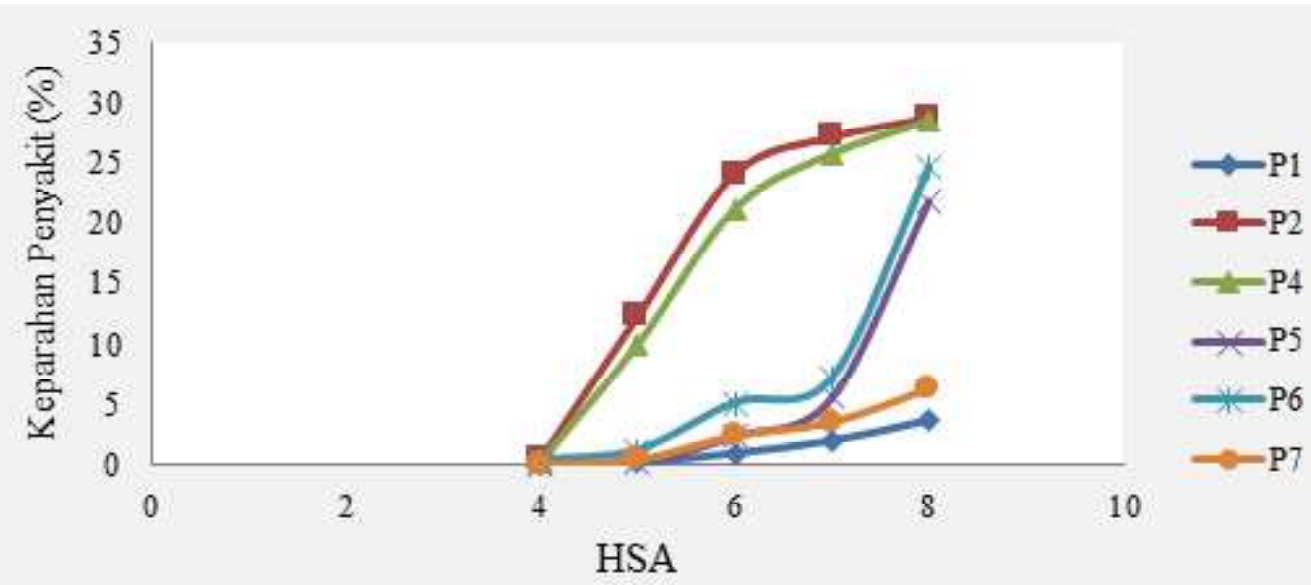

Gambar 4. Grafik pengaruh perlakuan ekstrak daun pepaya dan fungisida sintetik terhadap perkembangan penyakit antraknosa pada buah pepaya. 
Tabel 2. Pengaruh perlakuan ekstrak daun pepaya dan fungisida sintetik terhadap kerapatan spora

\begin{tabular}{lc}
\hline Perlakuan & Kerapatan Spora/ml \\
\hline Kontrol Fungisida Sintetik & 87500 \\
Kontrol Tanpa Fungisida & 900000 \\
Ekstrak Daun Pepaya 10\% & 275000 \\
Ekstrak Daun Pepaya 20\% & 212500 \\
Ekstrak Daun Pepaya 30\% & 162500 \\
Ekstrak Daun Pepaya 40\% & 300000 \\
Ekstrak Daun Pepaya 50\% & 925000 \\
\hline F hitung & $2,437 \mathrm{TN}$ \\
F tabel & 2,573 \\
\hline
\end{tabular}

Keterangan : $*=$ Nyata $\quad \mathrm{TN}=$ Tidak Nyata

Tabel 3. Pengaruh perlakuan ekstrak daun pepaya dan fungisida sintetik terhadap perkecambahan spora setelah 14 jam

\begin{tabular}{lc}
\hline Perlakuan & Spora Berkecambah (\%) \\
\hline Kontrol Fungisida Sintetik & 91,50 \\
Kontrol Tanpa Fungisida & 79,00 \\
Ekstrak Daun Pepaya 10\% & 83,75 \\
Ekstrak Daun Pepaya 20\% & 93,75 \\
Ekstrak Daun Pepaya 30\% & 95,00 \\
Ekstrak Daun Pepaya 40\% & 44,50 \\
Ekstrak Daun Pepaya 50\% & 90,00 \\
\hline F hitung & $2,474 \mathrm{TN}$ \\
F tabel & 2,573 \\
\hline
\end{tabular}

Keterangan $: *=$ Nyata $\quad \mathrm{TN}=$ Tidak Nyata

antifungi karena dapat menghambat biosintesis asam nukleat (Kusumaningtyas dkk., 2008). Biosintesis asam nukleat yang terhambat menyebabkan proses penyusunan protein terganggu sehingga pertumbuhan jamur terganggu. Tetapi, ekstrak daun pepaya tidak menghambat kerapatan dan perkecambahan spora. Hal ini diduga karena senyawa aktif yang ada pada ekstrak daun pepaya tidak mampu menghambat jamur $C$. gloeosporioides pada fase generatif. Berdasarkan hasil tersebut maka ekstrak daun pepaya bersifat fungistatik (menghambat pertumbuhan jamur).

\section{Pengaruh Ekstrak Daun Pepaya terhadap} Intensitas Penyakit Antraknosa Pepaya.

Pengujian ekstrak daun pepaya terhadap intensitas penyakit antraknosa pada buah pepaya dilakukan dengan menggunakan perlakuan ekstrak daun pepaya terbaik dari hasil uji in-vitro. Hasil uji in-vitro didapatkan empat perlakuan terbaik yaitu 20, 30, 40, dan $50 \%$. Berdasarkan hasil tersebut maka pengujian intensitas penyakit antraknosa pepaya dilakukan menggunakan enam perlakuan yaitu P1 (kontrol fungisida sintetik), P2 (kontrol tanpa fungisida), 
P4 ( ekstrak daun pepaya 20\%), P5 (ekstrak daun pepaya 30\%), P6 (ekstrak daun pepaya 40\%), dan P7 (ekstrak daun pepaya 50\%).

Buah pepaya mulai bergejala pada 4 hsa (hari setelah aplikasi). Setelah buah bergejala, pengamatan terhadap keterjadian dan keparahan penyakit antraknosa dimulai. Pengamatan dihentikan pada 8 hsa karena keparahan penyakit dari salah satu buah telah mencapai $100 \%$.

Hasil analisis ragam ekstrak daun pepaya dan fungisida sintetik terhadap keterjadian penyakit antraknosa pada buah pepaya menunjukan adanya pengaruh yang nyata dalam menghambat keterjadian penyakit tersebut pada 5 dan 6 hsa (Tabel 4). Sedangkan pada 4, 7, dan 8 hsa ekstrak daun pepaya dan fungisidasintetik tidak berpengaruhnyatamenghambat keterjadian penyakit antraknosa pada buah pepaya.

Berdasarkan hasil uji BNT, pengaruh perlakuan ekstrak daun pepaya konsentrasi 30 dan $50 \%$ serta fungisida sintetik menunjukan perbedaan yang nyata dalam menghambat keterjadian penyakit antraknosa pada buah pepaya dibandingkan dengan kontrol tanpa fungisida pada 5 hsa. Kemudian pada 6 hsa hanya ekstrak daun pepaya konsentrasi $30 \%$ yang menunjukan perbedaan yang nyata dalam menghambat keterjadian penyakit tersebut dibandingkan dengan kontrol tanpa fungisida. Berdasarkan hasil tersebut, kemampuan ekstrak daun pepaya konsentrasi 30 dan $50 \%$ dalam menghambat keterjadian penyakit antraknosa pada buah pepaya sama dengan kontrol fungisida sintetik berbahan aktif propineb $70 \%$ pada 5 hsa. Sedangkan pada 6 hsa hanya ekstrak daun pepaya konsentrasi 30\% yang dapat menghambat keterjadian penyakit antraknosa pada buah pepaya. Analisis ragam pengaruh ekstrak daun pepaya dan fungisida sintetik terhadap keparahan penyakit

Tabel 4. Pengaruh perlakuan ekstrak daun pepaya dan fungisida sintetik terhadap keterjadian penyakit antraknosa pada buah pepaya

\begin{tabular}{lccccc}
\hline \multirow{2}{*}{ Perlakuan } & \multicolumn{5}{c}{ Rata-rata keterjadian penyakit (\%) } \\
\cline { 2 - 6 } & $4 \mathrm{hsa}$ & $5 \mathrm{hsa}$ & $6 \mathrm{hsa}$ & $7 \mathrm{hsa}$ & $8 \mathrm{hsa}$ \\
\hline P1 & 0 & $12,5 \mathrm{a}$ & $65 \mathrm{ab}$ & 85 & 92,5 \\
P2 & 25 & $62,5 \mathrm{~b}$ & $82,5 \mathrm{~b}$ & 95 & 95 \\
P4 & 22,5 & $42,5 \mathrm{ab}$ & $65 \mathrm{ab}$ & 75 & 82,5 \\
P5 & 0 & $12,5 \mathrm{a}$ & $22,5 \mathrm{a}$ & 55 & 85 \\
P6 & 22,5 & $60 \mathrm{ab}$ & $90 \mathrm{ab}$ & 95 & 95 \\
P7 & 10 & $22,5 \mathrm{a}$ & $57,5 \mathrm{ab}$ & 80 & 90 \\
\hline F hitung & 1,171 & 3,241 & 2,819 & 1,251 & 0,350 \\
\hline F tabel & 2,773 & 2,773 & 2,773 & 2,773 & 2,773 \\
\hline Kesimpulan & TN & $*$ & $*$ & TN & TN \\
\hline BNT 0,05 & - & 3,767 & 4,176 & - & - \\
\hline
\end{tabular}

Keterangan : P1 = Fungisida sintetik, P2 = Kontrol tanpa fungisida, P3 = Ekstrak daun pepaya 10\%, P4 = Ekstrak daun pepaya $20 \%$, P5 = Ekstrak daun pepaya $30 \%$, P6 = Ekstrak daun pepaya 40\%, P7 = Ekstrak daun pepaya $50 \%$, $\mathrm{TN}=$ Tidak Nyata, $*=$ Nyata. 
antraknosa pada buah pepaya menunjukan tidak adanya pengaruh yang nyata dalam menghambat keparahan penyakit tersebut mulai dari 4 sampai 8 hsa (Tabel 5). Namun, pada perlakuan P5, P6, dan P7 menunjukan bahwa ekstrak daun pepaya memiliki potensi untuk menghambat keparahan penyakit antraknosa pada buah pepaya terutama $\mathrm{P} 7$ (Gambar4). Pada gambar tersebut, terlihat bahwa pengaruh perlakuan ekstrak daun pepaya konsentrasi 50\% berada jauh dibawah kontrol tanpa fungisida.

Penyakit berkembang seiring dengan berjalannya waktu. Pemberian ekstrak daun pepaya mampu menghambat perkembangan penyakit antraknosa pada buah pepaya. Ekstrak daun pepaya konsentrasi $50 \%(\mathrm{P} 7)$ menunjukan daya hambat yang paling kuat dibandingkan dengan ekstrak daun pepaya konsentrasi lainnya(Gambar 5).

Tabel 5. Pengaruh perlakuan ekstrak daun pepaya dan fungisida sintetik terhadap keparahan penyakit antraknosa pada buah pepaya

\begin{tabular}{cccccc}
\hline & \multicolumn{5}{c}{ Rata-rata keterjadian penyakit (\%) } \\
\cline { 2 - 5 } Perlakuan & 4 hsa & 5 hsa & 6 hsa & 7 hsa & 8 hsa \\
\hline P1 & 0 & 0,196 & 0,978 & 2,041 & 3,762 \\
P2 & 0,42 & 12,268 & 24,093 & 27,16 & 28,752 \\
P4 & 0,28 & 10,015 & 21,24 & 25,783 & 28,527 \\
P5 & 0 & 0,279 & 2,414 & 5,561 & 21,854 \\
P6 & 0,347 & 1,166 & 5,089 & 7,193 & 24,694 \\
P7 & 0,107 & 0,454 & 2,407 & 3,496 & 6,211 \\
\hline F hitung & $1,072 \mathrm{TN}$ & $0,838 \mathrm{TN}$ & $0,724 \mathrm{TN}$ & $0,728 \mathrm{TN}$ & $0,442 \mathrm{TN}$ \\
F tabel & 2,773 & 2,773 & 2,773 & 2,773 & 2,773 \\
\hline
\end{tabular}

Keterangan : P1 $=$ Fungisida sintetik, $\mathrm{P} 2=$ Kontrol tanpa fungisida, $\mathrm{P} 3=$ Ekstrak daun pepaya $10 \%, \mathrm{P} 4=$ Ekstrak daun pepaya $20 \%, \mathrm{P} 5=$ Ekstrak daun pepaya $30 \%, \mathrm{P} 6=$ Ekstrak daun pepaya 40\%,P7 = Ekstrak daun pepaya $50 \%$, $\mathrm{TN}=$ Tidak Nyata,${ }^{*}=$ Nyata.

Tabel 6. Pengaruh perlakuan ekstrak daun pepaya dan fungisida sintetik terhadap nilai AUDPC antraknosa pada buah pepaya

\begin{tabular}{lc}
\hline Perlakuan & Rata-rata nilai AUDPC \\
\hline Kontrol Fungisida Sintetik & $1,395 \mathrm{a}$ \\
Kontrol Tanpa Fungisida & $18,539 \mathrm{c}$ \\
Ekstrak Daun Pepaya 20\% & $17,169 \mathrm{bc}$ \\
Ekstrak Daun Pepaya 30\% & $6,022 \mathrm{ab}$ \\
Ekstrak Daun Pepaya 40\% & $7,698 \mathrm{abc}$ \\
Ekstrak Daun Pepaya 50\% & $2,535 \mathrm{a}$ \\
\hline F hitung & 3,395 \\
\hline F tabel & 2,621 \\
\hline Kesimpulan & $*$ \\
\hline BNT 0,05 & 11,594 \\
\hline
\end{tabular}

Keterangan $: *$ Nyata $\quad \mathrm{TN}=$ Tidak Nyata 
Hasil analisis ragam pengaruh ekstrak daun pepaya dan fungisida sintetik terhadap perkembangan penyakit antraknosa pada buah pepaya menunjukan adanya pengaruh yang nyata dalam menghambat perkembangan penyakit tersebut (Tabel 6).

Hasil uji BNT perkembangan penyakit antraknosa pada buah pepaya memperlihatkan pengaruh perlakuan ekstrak daun pepaya konsentrasi 30 dan 50\% menunjukan perbedaan yang nyata dalam menghambat perkembangan penyakit tersebut dibandingkan dengan kontrol tanpa fungisida. Selain itu, pengaruh fungisida sintetik berbahan aktifpropineb $70 \%$ menunjukan perbedaan yang nyata dalam menghambat perkembangan penyakit antraknosa pada buah pepaya dibandingkan dengan kontrol tanpa fungisida. Berdasarkan hasil tersebut, kemampuan ekstrak daun pepaya 30 dan 50\% dalam menghambat pertumbuhan koloni C. gloeosporioides sama dengan kontrol fungisida sintetik berbahan aktif propineb $70 \%$.
Pengaruh konsentrasi ekstrak daun pepaya terhadap laju perkembangan penyakit antraknosa pada buah pepaya menunjukan bahwa ekstrak daun pepaya konsentrasi 50\% memiliki nilai AUDPC terendah dibandingkan dengan ekstrak daun pepaya konsentrasi lainnya (Tabel 6). Hasil tersebut menunjukan bahwa ekstrak daun pepaya konsentrasi 50\% memiliki daya hambat yang paling kuat terhadap perkembangan penyakit antraknosa pada buah pepaya, karena semakin rendah nilai AUDPC maka daya hambat terhadap perkembangan penyakit dari perlakuan semakin kuat.

Hasil uji polinomial pengaruh konsentrasi ekstrak daun pepaya terhadap laju perkembangan penyakit antraknosa pada buah pepaya menunjukan pola yang linier, yang disajikan dengan persamaan ( $\mathrm{Y}$ $=-1,6853 \mathrm{x}+100,35)$. Hasil tersebut menunjukan bahwa semakin tinggi konsentrasi maka nilai AUDPC semakin rendah dan daya hambat terhadap perkembangan penyakit semakin kuat (Gambar 6).

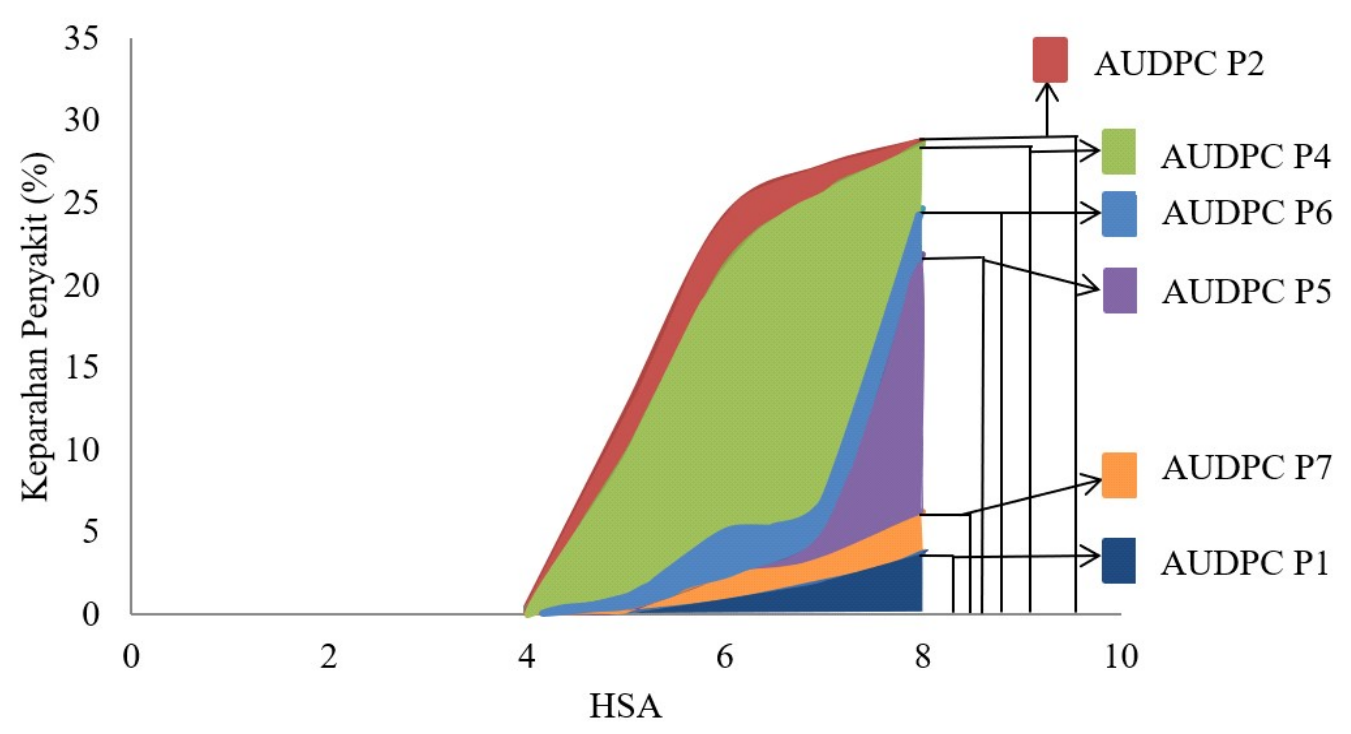

Gambar 5. Diagram area under the disease progress curve (AUDPC) antraknosa pada buah pepaya pengaruh dari ekstrak daun pepaya dan fungisida sintetik. 
Hasil pengujian secara in-vivo menunjukan bahwa ekstrak daun pepaya menghambat intensitas penyakit antraknosa pada buah pepaya. Ekstrak daun pepaya efektif menghambat keterjadian penyakit dan perkembangan penyakit antraknosa pada buah pepaya, bahkan memiliki efektifitas yang sama dengan fungisida sintetik berbahan aktif propineb $70 \%$. Akan tetapi ekstrak daun pepaya dan fungisida sintetik tidak menunjukan pengaruh yang nyata terhadap keparahan penyakit pada buah pepaya. Berdasarkan penelitian Ariani (2016), yang menggunakan ekstrak daun pepaya sebagai fungisida nabati terhadap jamur C. capsici penyebab penyakit antraknosa pada tanaman cabai merah (Capsicum annuum L.). Hasil penelitian menunjukan bahwa ekstrak daun pepaya dengan konsentrasi 5\% dan jenis kelamin betina merupakan ekstrak yang terbaik untuk menekan perkembangan penyakit antraknosa pada buah cabai merah dibandingkan dengan konsentrasi dan jenis ekstrak daun pepaya yang lain. Selain itu, Yulianty dkk. (2018) menggunakan ekstrak daun pepaya sebagai fungisida nabati untuk mengendalikan jamur Colletotrichum sp. penyebab penyakit antraknosa pada cabai (Capsicum annuит L.), hasil penelitian memperlihatkan bahwa ekstrak daun pepaya mampu memperlambat munculnya gejala pada buah cabai.

Hasil uji lanjut polinomial menunjukan perlakuan ekstrak daun pepaya dengan berbagai tingkat konsentrasi membentuk pola yang linier terhadap pertumbuhan koloni C. gloeosporioides dan perkembangan penyakit antraknosa pada buah pepaya. Pola linier menunjukan bahwa semakin tinggi konsentrasi ekstrak daun pepaya maka nilai AUDPC semakin rendah serta daya hambat terhadap pertumbuhan koloni C. gloeosporioides dan perkembangan penyakit antraknosa pada buah pepaya semakin kuat. Hal ini serupa dengan hasil penelitian Suleiman (2010) yang menggunakan ekstrak daun pepaya untuk menghambat pertumbuhan miselium jamur Alternaria solani pada umbi ubi. Hasil penelitian

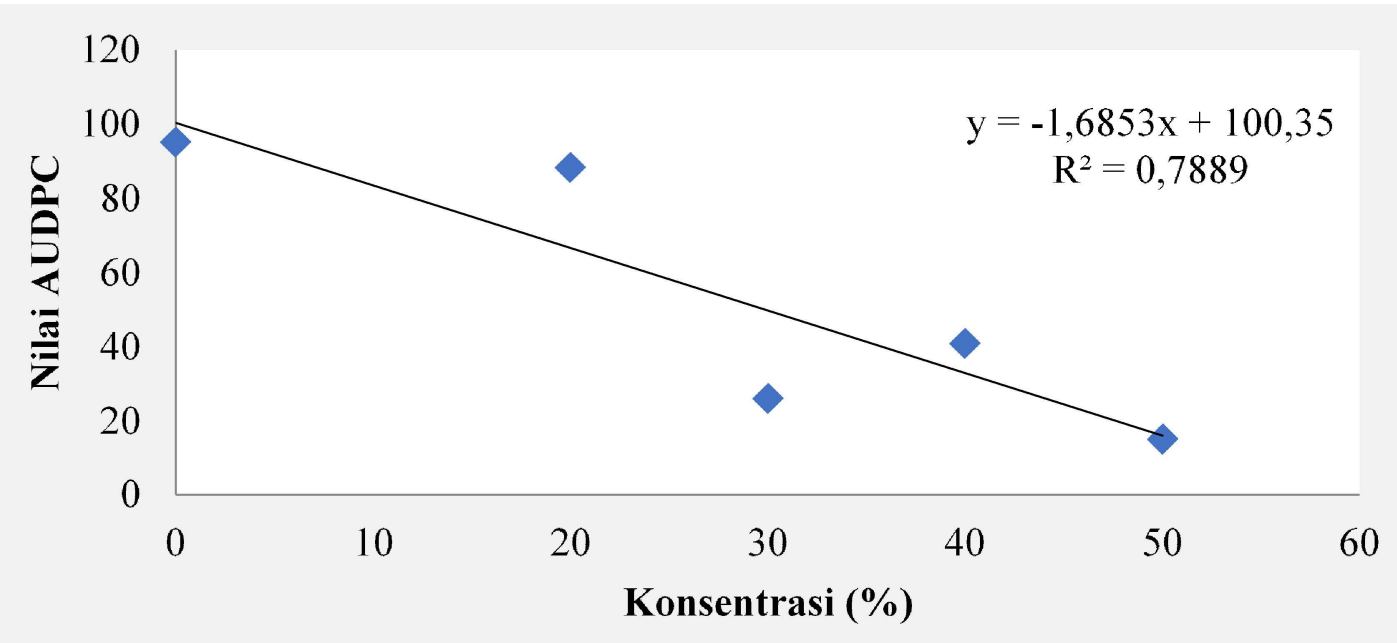

Gambar 6. Grafik perkembangan penyakit antraknosa pada buah pepaya dari beberapa konsentrasi ekstrak daun pepaya. 
menunjukkan bahwa semakin tinggi konsentrasi ekstrak daun pepaya daya hambat terhadap pertumbuhan miselium jamur Alternaria solani semakin kuat.

Penelitian ini menunjukan bahwa ekstrak daun pepaya memiliki efektifitas yang sama dengan fungisida sintetik. Ekstrak daun pepaya dan fungisida sintetik efektif dalam menghambat pertumbuhan koloni jamur C. gloeosporioides, keterjadian penyakit, dan laju perkembangan penyakit antraknosa pada buah pepaya. Berdasarkan hasil tersebut ekstrak daun pepaya dapat dijadikan alternatifpengendalian penyakit antraknosa padabuah pepaya dibandingkan menggunakan fungisida sintetik berbahan aktif propineb $70 \%$.

\section{KESIMPULAN}

Kesimpulan yang diperoleh dari penelitian ini yaitu ekstrak daun pepaya menghambat pertumbuhan koloni jamur C. gloeosporioides pada 2 sampai 7 hsi. Tetapi ekstrak daun pepaya tidak menghambat kerapatan dan perkecambahan spora. Ekstrak daun pepaya menghambat keterjadian penyakit antraknosa pada buah pepaya pada 5 dan 6 hsa maupun laju perkembangan penyakit antraknosa pada buah pepaya. Tetapi ekstrak daun pepaya tidak menghambat keparahan penyakit.

\section{UCAPAN TERIMA KASIH}

Ucapan terima kasih disampaikan kepada Bapak Prof. Dr. Ir. Cipta Ginting, M. Sc., atas ilmu serta saran dalam penyusunan jurnal.
Selain itu, kami juga berterima kasih kepada karyawan di Laboratorium Penyakit Tumbuhan dan Laboratorium Bioteknologi Fakultas Pertanian, Universitas Lampung.

\section{DAFTAR PUSTAKA}

Apriyadi, A.R., Wahyuni, W.S., Supartini, V. 2013. Pengendalian penyakit patik (Cercospora nicotianae) pada tembakau na oogst secara in-vivo dengan ekstrak daun gulma kipahit (Tithonia diversifolia). Berkala Ilmiah Pertanian 1 (2): 30-32.

Ariani, K. 2016. Uji efektivitas ekstrak daun pepaya (Carica papaya L.) sebagai fungisida alami terhadap jamur Colletotrichum capsici (Syd.) Butler \& Bisby penyebab penyakit antraknosa pada tanaman cabai merah (Capsicum annuum L.). Skripsi. Program Studi Biologi, Fakultas Matematika dan Ilmu Pengetahuan Alam, Universitas Lampung. $59 \mathrm{hlm}$.

Badan Pusat Statistik (BPS). Statistik Tanaman Buahbuahan dan Sayuran Tahunan Indonesia, 2016. http://www.bps.go.id. Diakses pada tanggal 30 Juli 2019.

Badan Pusat Statistik(BPS). Statistik Tanaman Buahbuahan dan Sayuran Tahunan Indonesia, 2017. http://www.bps.go.id. Diakses pada tanggal 30 Juli 2019.

Gabriel, B.P. \& Riyanto. 1989. Metarhizium anisopliae Taksonomi, Patologi, Produksi dan Aplikasinya. Proyek Pengembangan Perlindungan Tanaman Perkebunan. Direktorat Perlindungan Tanaman Perkebunan. Dapertemen Pertanian. Jakarta. $25 \mathrm{hlm}$. 
Ginting, C. 2013. Ilmu Penyakit Tumbuhan (Konsep dan Aplikasi). Lembaga Penelitian Universitas Lampung. Bandar Lampung. $203 \mathrm{hlm}$.

Kharisma, Y. 2017. Tinjauan Pemanfaatan Tanaman Pepaya Dalam Kesehatan. Fakultas Kedokteran Universitas Islam Bandung. Bandung.

Kusumaningtyas, E.L., Sukmawati., Astuti, E. 2008. Penentuan golongan bercak senyawa aktif dari ekstrak n-heksan Alpina galangal terhadap Candida albicans dengan bioautografi dan kromatografi lapis tipis. Jurnal Ilmu Ternak dan Veteriner 13(4) : 323-328.

Semangun, H. 2007. Penyaki-penyakit Tanaman Hortikultura di Indonesia. Gadjah Mada University Press. Yoyakarta. $845 \mathrm{hlm}$.
Septiana, W., Efri., Aeny, T.N. 2013. Pengaruh berbagai tingkat fraksi ekstrak buah mengkudu (M. citrifolia) terhadap C. capsici pada cabai (C. anum L.) secara in-vitro. Jurnal Agrotek Topika 1(2): 202-207.

Suleiman, M.N. 2010. Fungitoxic activity of neem and pawpaw leaves extracts on Alternaria solani, causal organism of yam rots. Advances in Environmental Biology 4(2): 159-161.

Yulianty.,LandeM.L., Handayani, T.T.2018.Effectiveness of carica papaya leaves extract in controlling anthracnose diseases caused by Colletotrichum sp.on red chilli (Capsicum annuum L.). Jurnal Mikologi Indonesia 2(1): 49-55. 